\title{
Collembolan community in broad-leaved forests and in conifer stands of Cryptomeria japonica in Central Japan
}

\author{
Motohiro Hasegawa(1), Kenji Fukuyama(2), Shun'ichi Makino(2), Isamu Okochi(2), Hiroshi Tanaka(3), \\ Kimiko Okabe (2), Hideaki Goto(3), Takeo Mizoguchi(4) and Tadashi Sakata(5) \\ ${ }^{(1)}$ Kiso Experimental Station, Forestry and Forest Products Research Institute, Fukushima 5473, Kiso, Nagano 397-0001, \\ Japan. E-mail: motohiro@ffpri.affrc.go.jp (2)Forestry and Forest Products Research Institute, Tsukuba, Ibaraki 305-8687, Japan. \\ E-mail: fukuchan@affrc.go.jp, makino@ffpri.affrc.go.jp, ohkou04@affrc.go.jp, kimikook@ffpri.affrc.go.jp (3)Kyusyu Research Center, Forestry and \\ Forest Products Research Institute, Kurokami 4-11-16, Kumamoto 860-0862, Japan. E-mail: hirop@ffpri.affrc.go.jp, gotohide@ffpri.affrc.go.jp \\ ${ }^{(4)}$ Kansai Research Center, Forestry and Forest Products Research Institute, Nagai-Kyutaro 68, Momoyama-cho, Fushimi-ku, Kyoto 612-0855, \\ Japan. E-mail: mizo@ffpri.affrc.go.jp ${ }^{(5)}$ Hokkaido Research Center, Forestry and Forest Products Research Institute, Hitsujigaoka 7, Toyohira-ku, \\ Sapporo, Hokkaido 062-8516, Japan. E-mail: sakata@ffpri.affrc.go.jp
}

Abstract - Collembolan communities in conifer plantations (Japanese cedar, Cryptomeria japonica) and secondary deciduous broad-leaved forests of varying ages were investigated to determine the extent to which forest conversion (broad-leaved to coniferous) affects the species richness and assemblage composition of Collembola in central Japan. Density and total species richness of Collembola not differed between the broad-leaved and cedar forests except immediately after clear-cutting. The amount of forest-floor organic matter was larger in cedar forests and positively correlated with the species richness of detritus feeders. Species richness of fungal feeders and sucking feeders positively correlated with the species richness of forest-floor plants. There was difference in collembolan species composition between the forest types. The age of the forests seemed to have only small importance for the collembolan community, except during the first four years after clear-cutting. The conversion to artificial cedar stands has not reduced the abundance or species richness of collembolan communities, but has affected community composition. Differences in species composition may be related to the ground floras.

Index terms: japanese cedar, species composition, feeding habit, undergrowth.

\section{Comunidade de Colêmbolos em florestas decíduas e em plantações da conífera Cryptomeria japonica no Japão central}

\begin{abstract}
Resumo - As comunidades de colêmbolos nas plantações da conífera Cryptomeria japonica (cedro japonês) e florestas decíduas secundárias de várias idades foram investigadas para determinar até que ponto a conversão da floresta decídua em conífera afeta a riqueza das espécies e a composição das comunidades de colêmbolos no Japão central. A densidade e a riqueza total de espécies de Collembola não foram diferentes entre as florestas decíduas e de cedro, exceto imediatamente depois do corte raso. A quantidade de matéria orgânica acumulada no solo foi maior sob cedro e positivamente correlacionada com a riqueza de espécies de detritívoros. A riqueza de espécies de fungívoros e sugadores foi positivamente correlacionada à riqueza de espécies de plantas do estrato herbáceo da floresta. Houve diferença na composição das espécies de colêmbolos entre os tipos de floresta. A idade das florestas parece ter pouca importância para a comunidade de colêmbolos, exceto nos primeiros quatro anos após o corte raso. Concluiu-se que a conversão da floresta decídua em plantações de cedro japonês não causou diminuição na abundância e na riqueza das espécies das comunidades de colêmbolos, mas afetou a composição dessas comunidades. As diferenças na composição das espécies podem ser relacionadas ao desenvolvimento de plantas do estrato herbáceo da floresta.
\end{abstract}

Termos para indexação: cedro japonês, composição de espécies, hábito alimentar, vegetação rasteira.

\section{Introduction}

In Japan, a major land-use change has been forest conversion from natural or secondary broad-leaved woodland to conifer plantation, mainly using the Japanese cedar (Cryptomeria japonica) and Hinoki cypress (Chamaecyparis obtusa). The area occupied by such plantations now represents about $30 \%$ of the total forest area of Japan (Japan Agriculture Statistics
Association, 2001), and the conversion process has been reported to reduce biodiversity and simplify community structures of some arthropod fauna (Maeto \& Sato, 2004; Makino et al., 2007). Early studies comparing faunas of forest sites (Watanabe, 1973; Kaneko, 1995) should now be supplemented by monitoring communites along chronosequences because collembolan community structures generally change as forests grow (Hasegawa et al., 2006). 
It has been shown that the soil arthropods, such as Collembola, may be sensitive to silvicultural practices (Huhta et al., 1967; Bird \& Chatarpaul, 1986) and plant community structures (Blair et al., 1994; Deharveng, 1996; Pinto et al., 1997; Elmer et al., 2004). However, other studies have indicated only a weak relation (Hågvar, 1982; Migge et al., 1998; Scheu et al., 2003; Salamon et al., 2004). The magnitude of such effects may depend on situation (e.g. climate, site history or tree species) or soil variables such as humidity, $\mathrm{pH}$, fertility, humus form and temperature (Verhoef, 1981; Hågvar, 1982; Ponge, 1993; Cassagne et al., 2003). These soil environment factors are in turn correlated with vegetation (Materna, 2004). The objective of this work was to determine differences in Collembola in broad-leaved forests and in conifer plantation, and to address possible causes for the differences.

\section{Materials and Methods}

The study area was located at the southern edge of the Abukuma Mountains, in northern Ibaraki, central Japan (approximately $36^{\circ} 50 \sim 56^{\prime} \mathrm{N}, \quad 140^{\circ} 34 \sim 35^{\prime} \mathrm{E}$, 580-800 m a.s.1.; mean annual air temperature $10.7^{\circ} \mathrm{C}$; mean annual precipitation $1,900 \mathrm{~mm}$ ). Planted forests contained two conifers, Cryptomeria japonica and Chamaecyparis obtusa. In deciduous forests, the dominant trees were Quercus serrata, Quercus mongolica and Fagus crenata (Table 1; Inoue, 2003).
Two chronosequences were sampled: one (B series, Table 1) containing eight stands of deciduous forest of different ages $(1,4,12,24,51,54,71$ and $\geq 128$ years following clear-felling), and a second (C series, Table 1) containing eight stands of Cryptomeria japonica of different ages $(4,8,10,21,30,32,76$ and 77 years after planting). All sixteen stands were located within a $10 \times 10 \mathrm{~km}$ area.

Forest floors were sampled in April, August and November 2002 (deciduous forests) and 2004 (conifer plantation). In each stand, an $8 \times 8 \mathrm{~m}$ plot was set up and divided into eight subplots $(2 \times 4 \mathrm{~m})$. Samples from the forest floor were collected with a corer $(125 \mathrm{~mL}, 5-\mathrm{cm}$ depth,25- $\mathrm{cm}^{2}$ area)fromeachsubplot. Mostcollembolans occur in the litter layer and the upper mineral soil layer, within the top $5 \mathrm{~cm}$ of the profile. A total of 384 samples ( 2 forest types $\times 8$ sites $\times 8$ subplots $\times 3$ dates) were collected. Collembolans were extracted using Tullgren funnels at a constant temperature of $35^{\circ} \mathrm{C}$ for 72 hours. Specimens were allocated to feeding groups (fungus-feeders, detritus-feeders or sucking-feeders) by analysis of gut contents, following Takeda \& Ichimura (1983) and Hasegawa \& Takeda (1995).

Litter samples for chemical parameters and respiration analyses were taken from five plots in each forest site in July 2003. In each of them, litter was taken from a $25 \times 25 \mathrm{~cm}$ subquadrate, weighed, air-dried at $40^{\circ} \mathrm{C}$ for 72 hours, and finally reweighed. The standard errors of five replicates were 8 to $15 \%$ of the average values. Cores of $100 \mathrm{~mL}$ of the top $5 \mathrm{~cm}$ of soil were collected for chemical analysis. For soil $\mathrm{pH}$ and $\mathrm{EC}$ analysis, $5 \mathrm{~g}$

Table 1. Forest floor and soil (0-5 cm) environmental variables at each site of broad-leaved forest (B) and conifer plantation (C).

\begin{tabular}{|c|c|c|c|c|c|c|}
\hline Site $^{(1)}$ & $\begin{array}{c}\text { Forest floor mass } \\
\left(\mathrm{g} \mathrm{m}^{-2}\right)\end{array}$ & $\begin{array}{l}\text { Forest floor water } \\
\text { content }(\%)\end{array}$ & $\begin{array}{l}\text { Soil respiration } \\
\left(\mu \mathrm{g} \mathrm{CO}_{2} \mathrm{~m}^{-2} \mathrm{~s}^{-1}\right)\end{array}$ & $\begin{array}{c}\mathrm{pH}(\mathrm{KCl}) \\
(1: 5)\end{array}$ & $\begin{array}{c}\mathrm{EC} \\
\left(\mathrm{ds} \mathrm{\textrm {m } ^ { - 1 }}\right)\end{array}$ & $\mathrm{C} / \mathrm{N}$ \\
\hline B1 & 514 & 63 & 16.1 & 3.5 & 2.8 & 25 \\
\hline B4 & 394 & 242 & 20.1 & 3.6 & 2.8 & 15 \\
\hline B24 & 471 & 171 & 17.3 & 4.3 & 1.4 & 18 \\
\hline B51 & 657 & 246 & 18.6 & 3.6 & 1.6 & 17 \\
\hline B54 & 597 & 232 & 22.1 & 3.5 & 2.4 & 16 \\
\hline B71 & 633 & 123 & 15.6 & 3.5 & 1.8 & 19 \\
\hline $\mathrm{C} 4$ & 1,007 & 55 & 19.3 & 3.6 & 3.2 & 23 \\
\hline $\mathrm{C} 8$ & 496 & 80 & 21.2 & 4.1 & 2.4 & 18 \\
\hline $\mathrm{C} 10$ & 635 & 94 & 15.9 & 4.2 & 3.2 & 19 \\
\hline $\mathrm{C} 21$ & 2,142 & 139 & 20.5 & 4.2 & 1.8 & 19 \\
\hline $\mathrm{C} 30$ & 1,134 & 164 & 28.4 & 3.9 & 1.4 & 19 \\
\hline $\mathrm{C} 32$ & 1,556 & 125 & 21.3 & 3.9 & 1.4 & 20 \\
\hline C76 & 1,543 & 147 & 24.0 & 3.7 & 3.2 & 21 \\
\hline $\mathrm{C} 77$ & 1,426 & 197 & 20.2 & 4.0 & 2.0 & 21 \\
\hline
\end{tabular}

${ }^{(1)}$ The numbers after the alphabet letters refers to the age after clear-cutting. 
of fresh soil mixed with $25 \mathrm{~mL}$ of a $0.1 \mathrm{~mol} \mathrm{~L}^{-1} \mathrm{KCl}$ solution (for $\mathrm{pH}$ ) or deionized water (for EC). A glass electrode (HM14P, DKK-Toa Corp., Tokyo, Japan) was used to measure $\mathrm{pH}$ and soil EC was measured with a conductivity cell electrode (SC82, Yokogawa Electric Corp., Tokyo, Japan). Soil organic matter was determined by mass loss on ignition after burning in an electric furnace $\left(1,000^{\circ} \mathrm{C}\right.$, for 1 hour $)$. Total carbon and nitrogen concentrations in soil were measured with a NC analyzer (Sumigraph NC-900, SCAS Ltd., Japan). Samples for soil respiration measurements were collected from mineral surface soil at 0 to $4 \mathrm{~cm}$ depth using a 400-mL cylindrical sampler with five replicates at each plot and sieved through a 2-mm mesh to remove roots and coarse organic particles. Subsamples of about $40 \mathrm{~g}$ were then incubated in sealed $650-\mathrm{mL}$ containers at $15^{\circ} \mathrm{C}$ for two days. After incubation, the $\mathrm{CO}_{2}$ concentrations in the container were measured at 0 , 2.5 and 5 hours at $15^{\circ} \mathrm{C}$ using an infrared gas analyzer (ZFP9, Fuji Electric Co., Japan). Carbon/nitrogen ratio and $\mathrm{pH}$ were also determined.

We established a belt transect $(10 \times 100 \mathrm{~m})$ at each site from September 2000 to October 2003. The DBH (diameter at breast height) above $5 \mathrm{~cm}$ was recorded for all trees and vines at or above $2 \mathrm{~m}$ height in forty $5 \times 5 \mathrm{~m}$ quadrats along a $100-\mathrm{m}$ transect line. The frequency of trees smaller than $5 \mathrm{~cm}$ in DBH was also determined. Forest-floor vegetation with a height of less than $2 \mathrm{~m}$ (designated as forest-floor plants) was estimated following the Braun-Blanquet method using 1x1-m quadrats. Physical and chemical parameters of soil were compared using ANOVA (SYSTAT 5.2.1 for Mac; SYSTAT Inc., Evanston, USA). To compare collembolan density between forest types, we used generalized linear models (GLM) with the assumption of negative binominal distribution for the number of individuals, following Sileshi (2008). To compare species richness, we used generalized linear models (GLM) with the assumption of Poisson distribution (R version 2.4.1; R Development Core Team, 2006).

Pooled data derived from three sampling occasions were used to determine Spearman rank correlation coefficients for collembolan density using SYSTAT 5.2.1 for Mac (SYSTAT Inc., Evanston, USA). Detrended correspondence analysis (DCA) for species richness scores and environmental variables was carried out with Canoco for Windows, Version 4.5 (Ter Braak \& Šmilauer, 2002). In DCA, only those species with a total count of at least three individuals were included. Population data were transformed to $\log _{10}(x+1)$. Detrending was conducted using second order polynomials.

To investigate the effects of plant community species composition on collembolans, Spearman rank correlation coefficients between the DCA first axis scores of the collembolan group ordination and those of the plant community group ordination were calculated. The plant community was divided into three groups: trees with $\mathrm{DBH} \geq 5 \mathrm{~cm}$, trees with $\mathrm{DBH}<5 \mathrm{~cm}$ and forest-floor plants. In DCA of trees with $\mathrm{DBH} \geq 5 \mathrm{~cm}$, the 1-year-old site and the 4-year-old site were excluded because there were no trees in these size classes. Likewise, in the DCA of forest-floor plants, the 1-year-old site was excluded. In DCA, only species with at least three individuals in total were used, and population data were transformed as $\log _{10}(\mathrm{x}+1)$. Indicator species analysis (Dufrêne \& Legendre, 1997) was performed with PC-ORD ver. 4 (McCune \& Mefford, 2006) to identify the representative species of Collembola for groups of sites identified by ordination. This analysis produced indicator values (IndVals) for each species in each group of sites, which were subsequently tested for statistical significance using a Monte Carlo technique.

\section{Results and Discussion}

Forest-floor organic detritus weight was significantly larger in the conifer forest than in the broad-leaved forest $(p<0.05)$, and tended to increase with forest age. Soil respiration showed an increase with forest age but did not show a significant difference between forest types. Water content of the forest-floor detritus, $\mathrm{pH}, \mathrm{EC}$ and $\mathrm{C} / \mathrm{N}$ were not different between forest types, and did not show any pattern with forest age (Table 1). Average DBH of trees was significantly larger in coniferous sites $(p<0.05, B 1, B 4, C 4$ were excluded in the calculation), while species richness of trees with $\mathrm{DBH}>5 \mathrm{~cm}(\mathrm{p}<0.01, \mathrm{~B} 1, \mathrm{~B} 4$ and $\mathrm{C} 4$ were excluded in the calculation) was significantly larger in broad-leaved sites $(\mathrm{p}<0.05)$. The species richness of forest-floor plants in the conifer sites decreases during middle age (20-30 years). That is due to the closing of the canopy by the planted trees, but after 30 years the crown is reopened by thinning. In contrast, species richness of forest-floor plants in broad-leaved trees 
gradually increased until 50 years after the clear-felling (Table 2).

Densities of collembolans ranged from $12,000-53,000$ ind. $\mathrm{m}^{-2}$ in the deciduous forests and from 5,700-79,000 ind. $\mathrm{m}^{-2}$ in conifer plantations (Figure 1). Average species richness percore ranged from $8-21$ in the deciduous forests and from 6-20 in the conifer plantations (Figure 2). Total species richness in each site on each sampling occasion ranged from 37-60 in deciduous forests and from 49-65 in conifer plantations. Total species richness found in eight forest sites through three samping occasions was 87 in deciduous forest and 95 in conifer plantations. The difference in both density and species richness between forest types was not significant.

Table 2. Tree and ground flora data for all sites of broadleaved forest (B) and conifer plantation (C): average diameter at breast height of trees ( $\mathrm{DBH}>5 \mathrm{~cm}$ ) and species richness of trees (DBH $>5 \mathrm{~cm}$ and $<5 \mathrm{~cm}$ ) and forest-floor plants.

\begin{tabular}{lcccc}
\hline Site $^{(1)}$ & $\begin{array}{c}\text { Average } \\
\text { DBH }(\mathrm{cm})\end{array}$ & $\begin{array}{c}\text { Tree species richness } \\
(\mathrm{DBH}>5)\end{array}$ & $\begin{array}{c}\text { Tree species } \\
\text { richness }(\mathrm{DBH}<5)\end{array}$ & $\begin{array}{c}\text { Plant species richness } \\
\text { (Forest floor) }\end{array}$ \\
\hline B1 & - & 0 & 0 & 59 \\
B4 & - & 0 & 31 & 113 \\
B12 & 7.3 & 14 & 42 & 70 \\
B24 & 8.7 & 20 & 46 & 87 \\
B51 & 13.4 & 16 & 25 & 116 \\
B54 & 17.1 & 21 & 14 & 127 \\
B71 & 12.1 & 30 & 29 & 32 \\
B128 & 17.2 & 20 & 23 & 116 \\
C4 & NA & 0 & 0 & 115 \\
C8 & 12.7 & 7 & 26 & 97 \\
C10 & 18.0 & 16 & 52 & 77 \\
C21 & 23.0 & 3 & 18 & 48 \\
C30 & 34.8 & 7 & 13 & 50 \\
C32 & 34.0 & 6 & 21 & 71 \\
C76 & 71.5 & 7 & 33 & 80 \\
(1) The numbers after the alphabet letters refers to the age after clear-cutting.
\end{tabular}

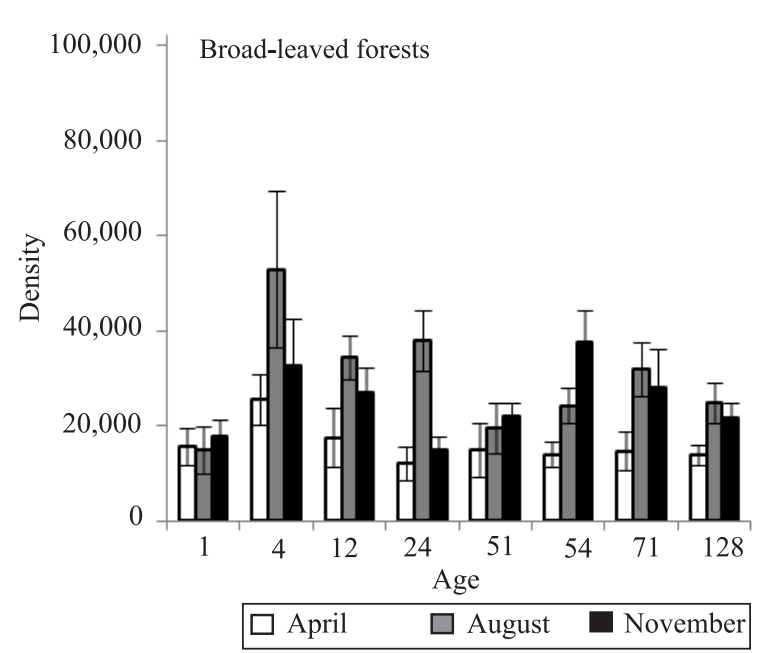

Detritus feeders were dominant both in density and in species richness. For density, average dominancy of detritus feeders was of $80 \%$ (deciduous) and $82 \%$ (conifer), and for species richness, of 52\% (deciduous) and $60 \%$ (conifer). Sucking feeders had the lowest values. The density of all feeding groups was not significantly different between forest types (Figure 3). Total species richness of detritus feeders in each site through three sampling occasions was slightly higher in conifer sites than in deciduous forests and the difference was significant $(\mathrm{p}<0.05)$ (Figure 4). The species richness of fungal feeders in deciduous forest tended to be higher but the difference was not significant between forest types. Also, the species richness of sucking feeders was not significantly different between forest types (Figure 4). The lack of a clear effect mirrors reforestation in central Europe, where conversion of beech forest to spruce did not produce a decline neither in density and species richness of Collembola (Scheu et al., 2003; Salamon et al., 2008), nor responded to the age of forest and tree species. In comparisons of pure and mixed stands of beech and spruce of varying ages, Salamon et al. (2008) also suggested that total abundance of Collembola did not show strong correlation with stand type or age. In their study, the dominant species in each stand were common and species richness tended to be lower in mixed forests.

Deharveng (1996) suggested that most of the forested areas of Europe have been severely disturbed since ancient times (Mediterranean area) or are devoid

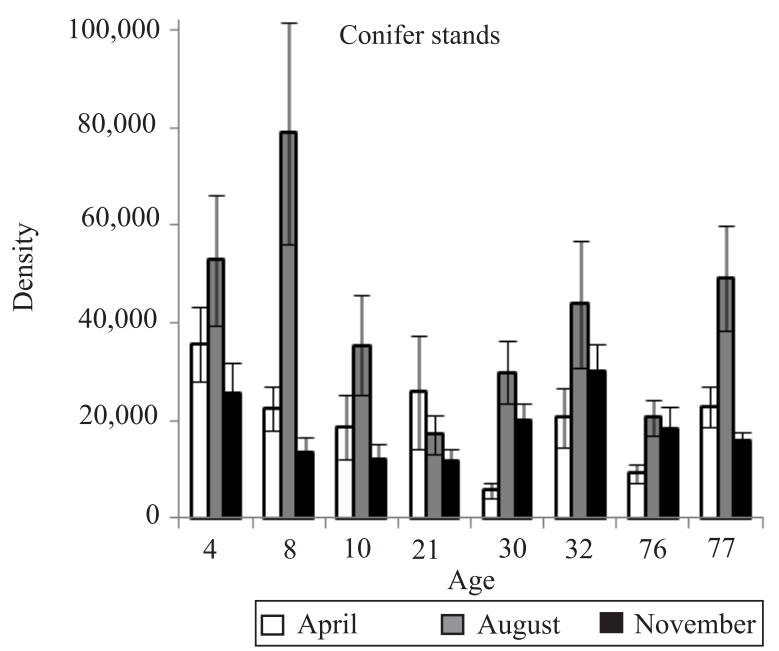

Figure 1. Mean density (individuals $\mathrm{m}^{-2}$ ) of total collembolans in broad-leaved forests (sampled in 2002) and in conifer stands (sample in 2004) of different ages (years) after clear-cutting. Bars indicate standard errors. 
of endemic taxa (Northern Europe). He indicated that the effects of forest modifications on biodiversity may be erratic in such situations. Our study sites are in the mountainous areas, which in the past had been subjected to human activities such as burning, cattle grazing and clear-cutting for fuel wood (Nakashizuka $\&$ Matsumoto, 2002). Thus, these past uses may have masked an effect of the conversion. In contrast, the reforestation in Southern Europe, commonly a conversion from Quercus to Eucalyptus or exotic pine, caused the decline of the collembolan community when compared with the natural vegetation (Jordana et al., 1987; Sousa et al., 1994). Sousa et al. (1994)

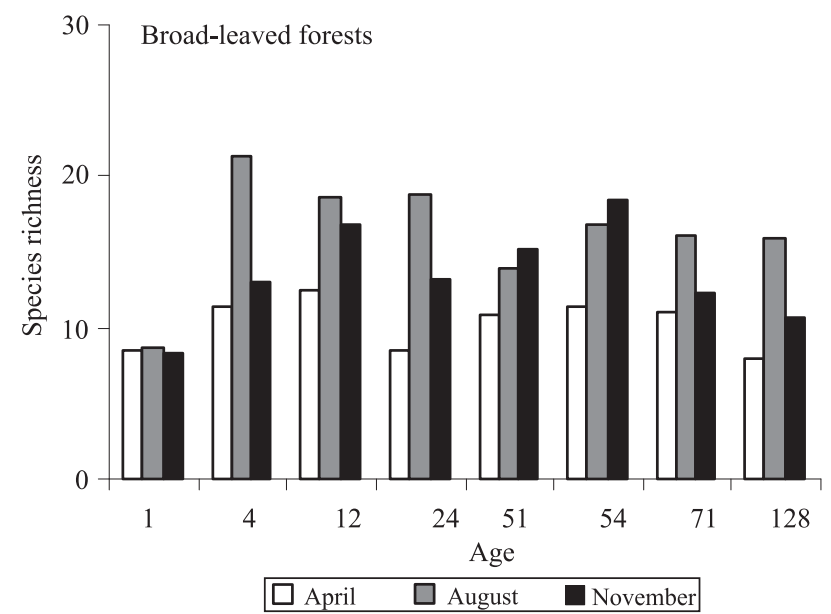

compared Collembola populations from a Quercus forest and a Eucalyptus plantation in Portugal, and showed degradation of the collembolan community structure, the fauna associated with the Quercus stands being richer and more abundant than under Eucalyptus. These authors also suggested that the disruption of the collembolan community might be related to the profound alterations of habitat characteristics, particularly frequent removal of shrub vegetation and leaf layer in the Eucalyptus plantation.

In their example of conversion from beech to spruce stands in the central Pyrenees, Cassagne et al. (2004) suggested that collembolan species diversity within

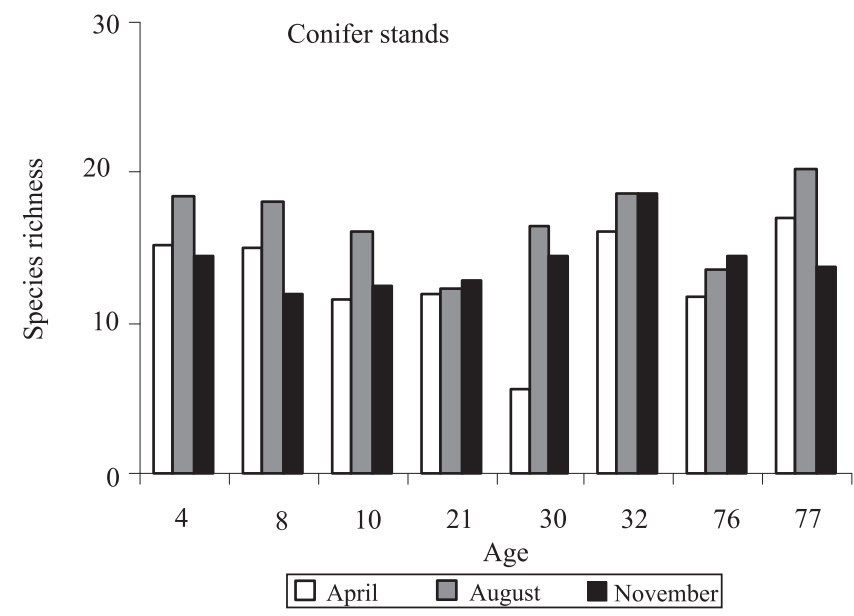

Figure 2. Average mean species richness per core of total collembolans in broad-leaved forests (sampled in 2002) and in conifer stands (sample in 2004) of different ages (years) after clear-cutting.
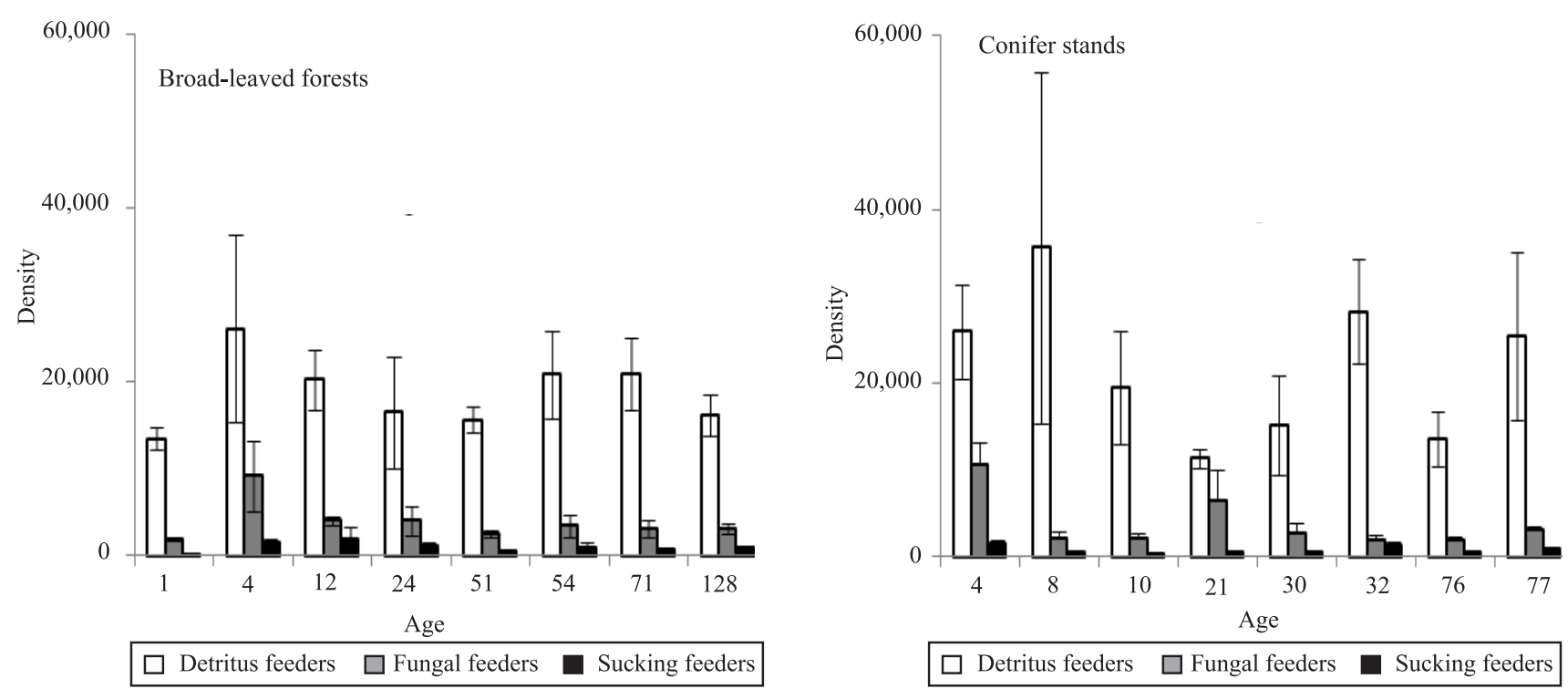

Figure 3. Density (no. of ind. $\mathrm{m}^{2}$ ) of feeding groups of collembolans in broad-leaved forests (sampled in 2002) and in conifer stands (sample in 2004) of different ages (years) after clear-cutting. Averages of data obtained on three sampling dates are given. Bars indicate standard errors. 
the A horizon was significantly lower under spruce at the early stage of the silvogenetic cycle. Differences in species composition were related to environmental changes. Among the various habitats or environmental variables, which influenced the collembolan community structures, the quantity and water content of the litter could be important environmental variables for the collembolan community (Verhoef, 1981; Takeda, 1987; Hasegawa, 2002). In the present study, there was more litter in coniferous forests, but water content was not significantly different. Hågvar (1982) examined the links between Collembola to plant communities, and considered that the more extreme environmental conditions are (e.g. soil moisture), the more likely it is that vegetation can determine the collembolan fauna. Thus, the conversion to coniferous forest in the present study may not have caused sufficient alteration of habitat characteristics to affect the collembolan fauna.

In a comparison between beech forest with spruce or fir plantation in the Pyrenees, Deharveng (1996) indicated a lack of collembolan diversity in the plantations. The endemic component of collembolan communities suffered a particulary severe loss in species richness and abundance, whereas non-endemic species were less affected. In our study, endemic species were not present in the study area. Thus, most of the species in the community may have a wide habitat tolerance. The density of total Collembola and each feeding group did not significantly correlate with the variables of soil and plant communities. Species richness of total Collembola also did not significantly correlate with the variables, but species richness of each feeding group significantly correlated with average DBH and litter quantity. Species richness of detritus feeders was also significantly correlated with DCA axis 1 of trees with DBH $>5 \mathrm{~cm}$, DCA axis 1 of trees with $\mathrm{DBH}<5 \mathrm{~cm}$ and DCA axis 2 of forest-floor plants (Table 3). Species richness of fungal feeders was positively correlated with the species richness of forest-floor plants and negatively correlated with DCA axis 2 of forest-floor plants. Species richness of sucking feeders was correlated positively with the species richness of forest-floor plants.

Communities associated with conifer and broad-leaved sites were relatively well defined in the ordination diagram for total Collembola and all feeding groups (Figure 5). Eigenvalues of the first two axes and their cumulative percentage in DCA were (respectively), $0.15,0.11$ and $31 \%$ for total collembolans, $0.15,0.08$ and $36 \%$ for detritus feeders, $0.30,0.17$ and $41 \%$ for fungal feeders and $0.41,0.29$ and $36 \%$ for sucking feeders. In the ordination diagram for total Collembola, broad-leaved sites except B4 and coniferous sites except $\mathrm{C} 4$ appear to be clumped. Therefore, these groups of sites were designated as 'broad-leaved group' and 'conifer group'. B4 and C4 were separated from the other sites, and were thus combined as the 'early-growth group'. Only four of the top 25 dominant species of Collembola were selected as indicator species of each group at $p<0.05$

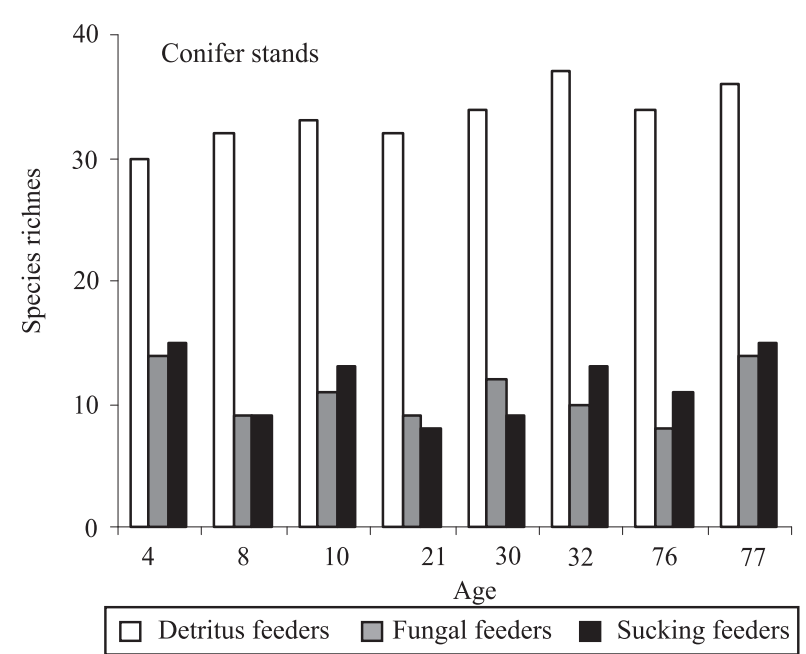

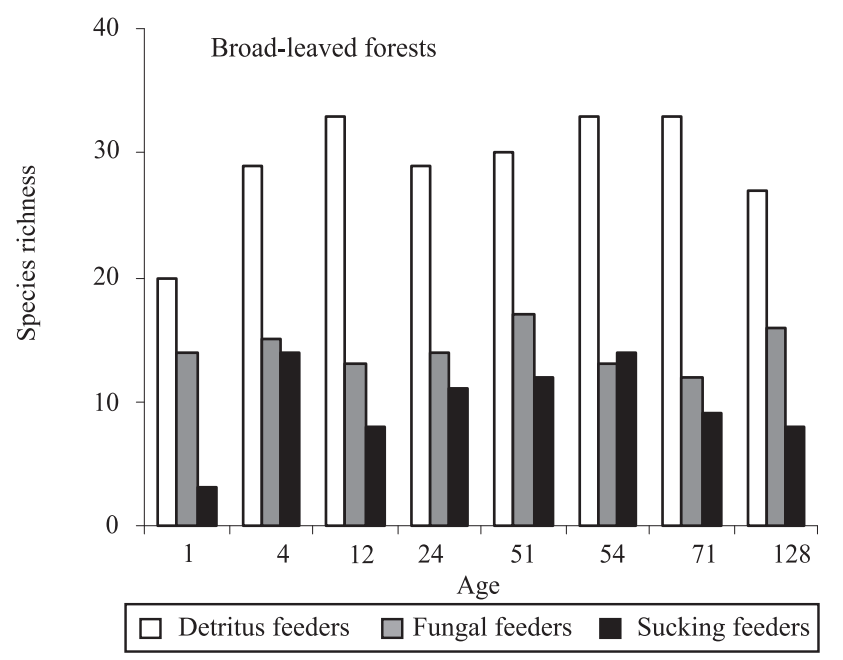

Figure 4. Species richness of feeding groups of collembolans in broad-leaved forests (sampled in 2002) and in conifer stands (sample in 2004) of different ages (years) after clear-cutting. Totals of data obtained on three sampling dates are given. 
level: Folsomina onychiurina, early growth; Folsomia quadrioculata, Broad-leaved; Megalothorax minimus, coniferous, Xenylla brevispina, coniferous. The coordinates of these four species in the DCA ordination diagram of total Collembola are shown with those of the top three dominant species (Figure $5 \mathrm{~A}$ ).

Site scores in DCA axis 1 of total Collembola and detritus feeders significantly correlated with the forest-floor mass, average DBH and DCA axis of each category of plant. Site scores in DCA axis 1 of fungal feeders significantly correlated with scores in DCA axis of each category of plant. Site scores in DCA axis 1 of sucking feeders significantly correlated with the forest-floor water content, species richness (DBH $>5 \mathrm{~cm}$ ), and average DBH and site scores in DCA axis of each category of plant. Fungal feeders and sucking feeders showed higher correlation coefficients with site scores in DCA axis 2 of forest-floor plants (Table 4). Despite the minor effects on the density and species richness in our study, DCA enabled a relatively clear distinction to be made between broad-leaved forests and coniferous forests. Materna (2004) showed that, although the collembolan species composition was quite similar, in beech and spruce forests $(77 \%$ shared species) the communities in each site were clearly delimited at both the qualitative (presence-absence) and quantitative (density of individual species) levels. Some species seemed to prefer one type of forest sites.

Hasegawa (2002) and Salamon et al.(2008) suggested that stand type and forest age affected Collembola communities, presumably via changes in the amount and quality of food resources, such as living plants and herb-litter materials. In our study, species richness of detritus feeders was significantly correlated with

Table 3. Spearman correlation coefficient for pairwise comparisons between species richness of each feeding group and variables of the forest-floor and plant communities ${ }^{(1)}$.

\begin{tabular}{lccc}
\hline & $\begin{array}{c}\text { Detritus } \\
\text { feeders }\end{array}$ & $\begin{array}{c}\text { Fungal } \\
\text { feeders }\end{array}$ & $\begin{array}{c}\text { Sucking } \\
\text { feeders }\end{array}$ \\
\hline Litter quantity & 0.609 & $\mathrm{~ns}$ & $\mathrm{~ns}$ \\
Average DBH & 0.745 & $\mathrm{~ns}$ & $\mathrm{~ns}$ \\
Species richness (Forest floor) & $\mathrm{ns}$ & 0.56 & 0.628 \\
DCA AX1 (DBH $>5 \mathrm{~cm})$ & 0.69 & $\mathrm{~ns}$ & $\mathrm{~ns}$ \\
DCA AX1 (DBH $<5 \mathrm{~cm})$ & -0.556 & $\mathrm{~ns}$ & $\mathrm{~ns}$ \\
DCA AX2 (Forest floor) & 0.64 & -0.655 & $\mathrm{~ns}$ \\
\hline
\end{tabular}

(1) Correlation coefficients were shown only when significant correlation $(\mathrm{p}<0.05)$ was detected. DBH, diameter at breast height; DCA, detrended correspondence analysis; AX, axis; ns, not significant. litter quantity. In addition, site scores in DCA axis 1 of detritus feeders (but not other trophic groups) were also significantly correlated with litter quantity. Dominant species of detritus feeders included $\mathrm{F}$ layer specialists (F. quadrioculata or F. onychiurina), which would be expected to respond to a well-developed litter layer. Species richness of fungal feeders correlated with the species richness of forest-floor plants and site scores in DCA axis 2 of forest-floor plants. Site scores in DCA axis 1 of fungal feeders showed a high correlation with site scores in DCA axis 2 of forest-floor plants. This suggests that the ground flora also affects fungus feeders. Materna (2004) found differences in the density of several collembolan species between patches with and without herb vegetation, and suggested that this could result from different microclimatic conditions, additional litter supply from herbs or interactions of Collembola with roots. In our definition, fungal feeders include surface-dwelling species (Hasegawa \& Takeda, 1995), whose microclimates are more directly dependent on the ground flora. Site scores of DCA axis 1 of sucking feeders were significantly correlated with the forest-floor water content. Sucking feeders take up organic matter or bacteria suspended in soil water (Singh, 1969). Therefore, water status in the litter may control this group.

Salamon et al. (2004) failed to find any correlation between species richness or functional group of plant and total diversity of collembolans in their experiment conducted in a series of plots with up to 32 plant species in a grassland community. Instead, they found that plant species composition, i.e. the identity of plant species in a mixture, affected densities of most of the Collembola and seems to be a more important determinant of Collembola abundance and diversity in grasslands than plant species richness per se or the number of plant functional groups. Milcu et al. (2006) investigation of effect of plant species diversity on the soil decomposer community showed positive or inconsistent effects. They also suggested that the identity of functional groups and the identity of plant species are more important for Collembolan performance than the diversity of plant species and functional groups per se. Salamon et al. (2004) indicated the importance of legumes, and Milcu et al. (2006) showed the importance of grasses to Collembola communities. In the present study, it was not clear what species in forest floors are important for the community structure of these feeding groups. 
Folsomina onychiurina emerged as an indicator of the successional stage of forest growth. This species is known to occur in different kinds of forests and open grassland litter (Potapov, 2001). Takeda (1987) showed that it was one of the dominant species of pine forests, while Tanaka \& Kitazawa (1982) showed that it maintained similar abundance in lawns and natural forests. Folsomia quadrioculata was selected
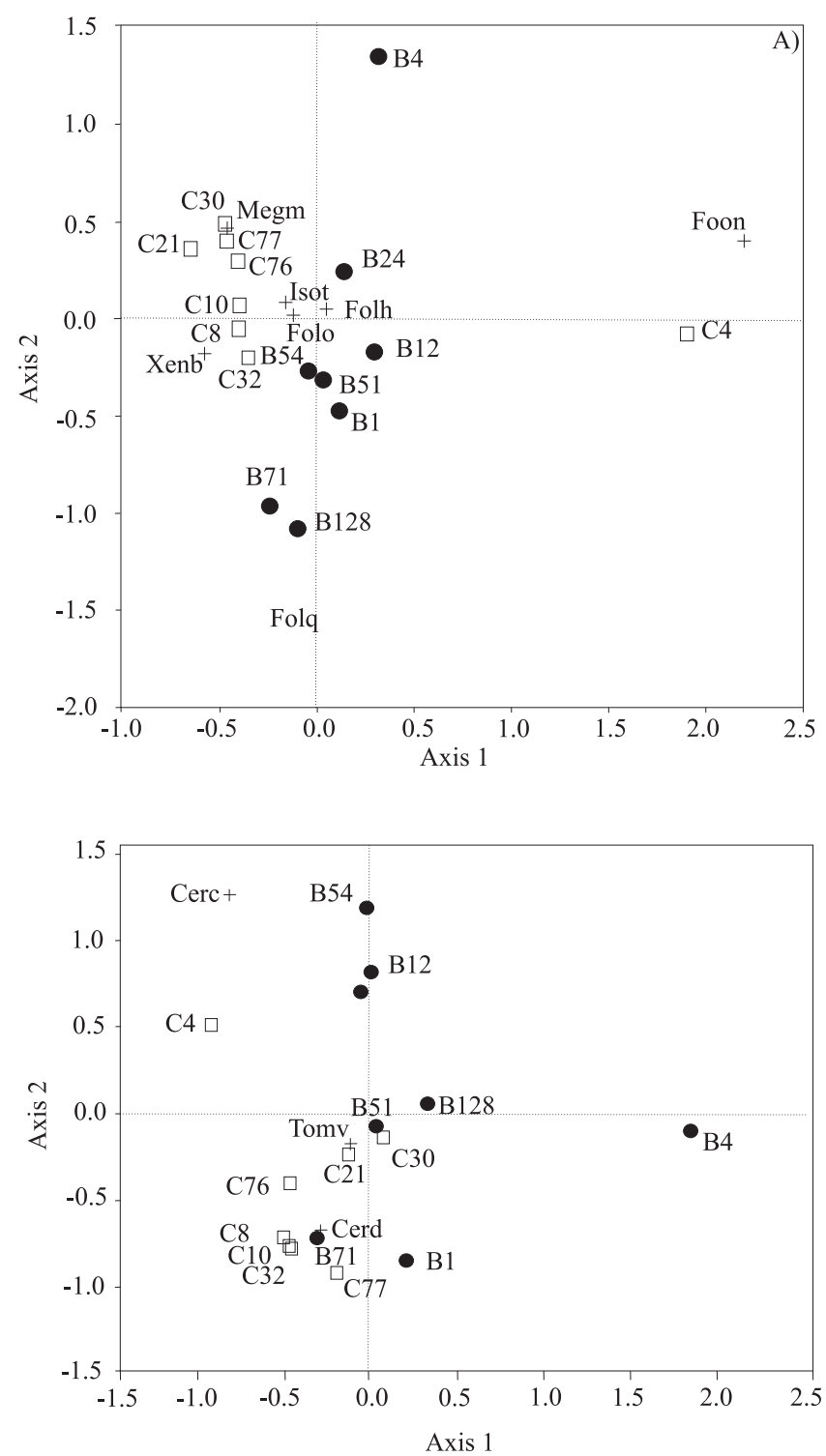

as an indicator of mature broad-leaved forest, despite the observation of Salamon et al. (2008) that it was more dominant in coniferous forests (Picea) than in broad-leaved forests. They attributed the dominance of the species in conifer forests to the higher humidity, compared with broad-leaved forests. In the present study, the water content of the forest floor was similar between forest types. Therefore, humidity was
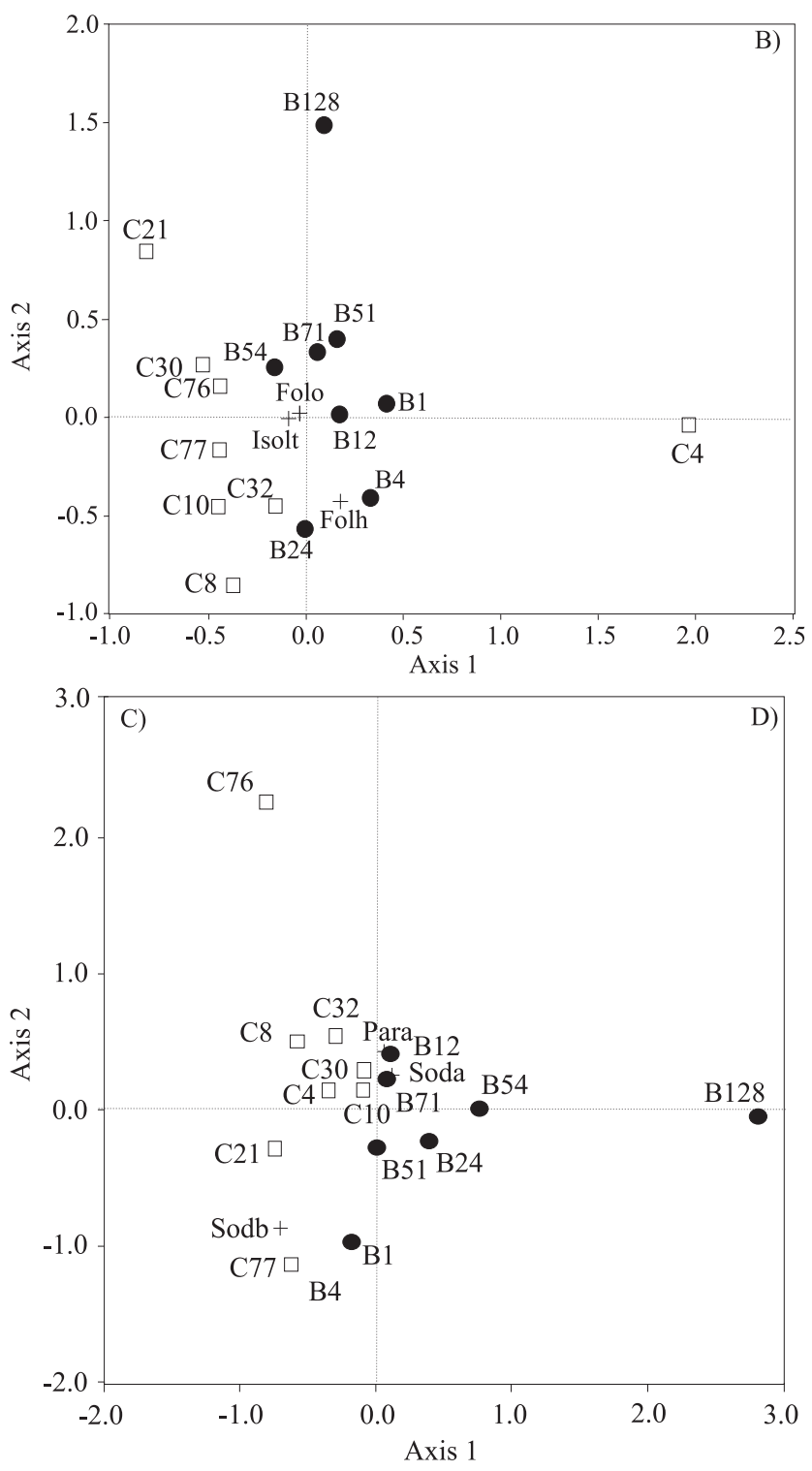

Figure 5. Detrended correspondence analysis (DCA) ordination diagrams for: A, total collembolans; B, detritus feeders; C, fungal feeders; and D, sucking feeders. Black circles show the positions of communities in broad-leaved forests, and white squares show the positions of communities in conifer plantations. Crosses show the positions of the main or indicator species. Folo, Folsomia octoculata; Isot, Isotomiella minor; Folh, F. hidakana; Folq, F. quadrioculata; Foon, Folsomina onychiurina; Xenb, Xenylla brevispina; Megm, Megalothorax minimus; Cerc, Ceratophysella communis; Cerd, C. denisana; Tomv, Tomocerus varius; Para, Paranura sp.1; Soda, Superodontella sp. a; Sodb, Superodontella sp. b. 
Table 4. Spearman correlation coefficient of detrended correspondence analysis axis 1 of total Collembola and each feeding group with variables of forest floor and plant community $^{(1)}$.

\begin{tabular}{lcccc}
\hline & Total & $\begin{array}{c}\text { Detritus } \\
\text { feeders }\end{array}$ & $\begin{array}{c}\text { Fungal } \\
\text { feeders }\end{array}$ & $\begin{array}{c}\text { Sucking } \\
\text { feeders }\end{array}$ \\
\hline Litter quantity & -0.659 & -0.556 & $\mathrm{~ns}$ & $\mathrm{~ns}$ \\
Litter water content & $\mathrm{ns}$ & $\mathrm{ns}$ & $\mathrm{ns}$ & -0.679 \\
Species richness $(\mathrm{DBH}>5 \mathrm{~cm})$ & $\mathrm{ns}$ & $\mathrm{ns}$ & $\mathrm{ns}$ & 0.738 \\
Average DBH & -0.775 & -0.736 & $\mathrm{~ns}$ & -0.643 \\
DCA AX1 (DBH $>5 \mathrm{~cm})$ & -0.665 & -0.692 & -0.544 & -0.659 \\
DCA AX1 (DBH $<5 \mathrm{~cm})$ & 0.684 & 0.723 & 0.543 & 0.596 \\
DCA AX2 (Forest Floor) & -0.512 & -0.5 & -0.785 & -0.744 \\
\hline
\end{tabular}

${ }^{(1)}$ Correlation coefficients were shown only when significant correlation at $5 \%$ of probability was detected; $\mathrm{DBH}$, diameter at breast height; $\mathrm{AX}$, axis; ns, nonsignificant.

apparently not a determinant of the distribution of the species. This species is known to be sensitive to different kinds of disturbances in Europe (Potapov, 2001). In addition, in Japan, Tanaka \& Kitazawa (1982) showed a sudden decrease in the density of the species from natural to secondary forest.

Xenylla brevispina was selected as an indicator of the conifer group, and it is known to be dominant in the canopies of coniferous forests (Yoshida \& Hijii, 2005). This species hatches in the soil and moves upwards into the canopy for growth and moves down to the soil for overwintering (Itoh, 1991). Yoshida \& Hijii (2006a) suggested that the densities of $X$. brevispina per unit weight of litter were similar between canopy litter and forest-floor litter. They also reported that the standing arboreal litter in a 33-year-old Cryptomeria forest was several times larger than that of the soil (Yoshida \& Hijii, 2006b). This suggests that a considerable part of the population of $X$. brevispina may be maintained by the arboreal litter in Cryptomeria forests. In the present study, the presence of arboreal litter and life strategy of $X$. brevispina may explain the larger population of the species in the conifer plantations (Cryptomeria forests) than in the deciduous broad-leaved forests, which seemed to have only a small amount of arboreal litter.

\section{Conclusions}

1. The conversion of broadleaved deciduous forest to cedar stands did not reduce the density and species richness of collembolans, but affected community structure.

2. The difference in species composition may be related to the accumulations of litter and changes in the ground flora. In silvicultural management, more attention should be given to the forest-floor plants to help maintain the biodiversity of soil fauna.

\section{Acknowledgements}

To the staff of the Insect Ecology Laboratory and the Kiso Experimental Station at the Forestry Forest Products Research Institute (FFPRI), for their help in the field research. This study was supported by research grant of the FFPRI, and partly by a grant-in-aid for Scientific Research sponsored by the Ministry of Education, Culture, Sports, Science and Technology, Japan.

\section{References}

BIRD, G.A.; CHATARPAUL, L. Effect of whole-tree and conventional forest harvest on soil microarthropods. Canadian Journal of Zoology, v.64, p.1986-1993, 1986.

BLAIR, J.M.; PARMELEE, R.W.; WYMAN, R.L. A comparison of the forest floor invertebrate communities of four forest types in the northeastern United States. Pedobiologia, v.38, p.146-160, 1994.

CASSAGNE, N.; BAL-SERIN, M.C.; GERS, C.; GAUQUELIN, T. Changes in humus properties and collembolan communities following the replanting of beech forests with spruce. Pedobiologia, v.48, p.267-276, 2004.

CASSAGNE, N.; GERS, C.; GAUQUELIN, T. Relationships between Collembola, soil chemistry and humus types in forest stands (France). Biology and Fertility of Soils, v.37, p.355-361, 2003.

DEHARVENG, L. Soil Collembola diversity, endemism, and reforestation: a case study in the Pyrenees (France). Conservation Biology, v.10, p.74-84, 1996.

DUFRÊNE, M.; LEGENDRE, P. Species assemblages and indicator species: the need for a flexible asymmetrical approach. Ecological Monographs, v.67, p.345-366, 1997.

ELMER, M.; LA FRANCE, M.; FORSTER, G.; ROTH, M. Changes in the decomposer community when converting spruce monocultures to mixed spruce/beech stands. Plant and Soil, v.264, p.97-109, 2004.

HÅGVAR, S. Collembola in Norwegian coniferous forest soils. I. Relations to plant communities and soil fertility. Pedobiologia, v.24, p.255-296, 1982.

HASEGAWA, M. The response of collembolan community to the amount and composition of organic matter of a forest floor. Pedobiologia, v.46, p.353-364, 2002.

HASEGAWA, M.; FUKUYAMA, K.; MAKINO, S.; OKOCHI, I.; GOTO, H.; MIZOGUCHI, T.; SAKATA, T.; TANAKA, H. Collembolan community dynamics during deciduous forests regeneration in Japan. Pedobiologia, v.50, p.117-126, 2006.

HASEGAWA, M.; TAKEDA, H. Changes in feeding attributes of four collembolan populations during the decomposition process of pine needles. Pedobiologia, v.39, p.155-169, 1995.

HUHTA, V.; KARPPINEN, E.; NURMINEN, M.; VALPAS, A. Effect of silvicultural practices upon arthropod, annelid and nematode populations in coniferous forest soil. Annales Zoologici Fennici, v.4, p.87-145, 1967.

ITOH, R. Growth and lifecycleofanarboreal Collembola, Xenyllabrevispina Kinoshita with special reference to its seasonal migration between tree and forest floor. Edaphologia, v.45, p.33-48, 1991. 
JAPAN AGRICULTURE STATISTICS ASSOCIATION. Analysis of structure and forest management in Japanese forestry based on forestry census 2000 (in Japanese). Tokyo: Japan Agriculture Statistics Association, 2001.

JORDANA, R.; ARBERA, J.I.; MORAZA, L.; MONTENEGRO, E.; MATEO, M.D.; HERNANDEZ, M.A.; HERRERA, L. Effect of reafforestation by conifers in natural biotopes of middle and South Navarra (Northern Spain). Revue Suisse de Zoologie, v.94, p.491-502, 1987.

KANEKO, N. Community organization of oribatid mites in various forest soils. In: EDWARDS, C.A.; ABE, T.; STRIGANOVA, B.R. (Ed.). Structure and function of soil communities. Kyoto: Kyoto University, 1995. p.21-33.

MAETO, K.; SATO, S. Impacts of forestry on ant species richness and composition in warm-temperate forests of Japan. Forest Ecology and Management, v.187, p.213-223, 2004.

MAKINO, S.; GOTO, H.; HASEGAWA, M.; OKABE, K.; TANAKA, H.; INOUE, T.; OKOCHI, I. Degradation of longicorn beetle (Coleoptera, Cerambycidae, Disteniidae) fauna caused by conversion from broad-leaved to man-made conifer stands of Cryptomeria japonica (Taxodiaceae) in central Japan. Ecological Research, v.22, p.372-381, 2007.

MATERNA, J. Does forest type and vegetation patchiness influence horizontal distribution of soil Collembola in two neighbouring forest sites? Pedobiologia, v.48, p.339-347, 2004.

MCCUNE, B.; MEFFORD, M. J. PC-ORD: multivariate analysis of ecological data. Version 5. Oregon: MJM Software Design, 2006.

MIGGE, S.; MARAUN, M.; SCHEU, S.; SCHAEFER, M. The oribatid mite community (Acarina) of pure and mixed stands of beech (Fagus sylvatica) and spruce (Picea abies) of different age. Applied Soil Ecology, v.9, p.115-121, 1998.

MILCU, A.; PARTSCH, S.; LANGEL, R.; SCHEU, S. The response of decomposers (earthworms, springtails and microorganisms) to variations in species and functional group diversity of plants. Oikos, v.112, p.513-524, 2006.

NAKASHIZUKA, T.; MATSUMOTO, Y. (Ed.). Diversity and interaction in a temperate forest community: Ogawa Forest Reserve of Japan. Tokyo: Springer, 2002.

PINTO, C.; SOUSA, J.P.; GRAÇA, M.A.S.; DA GAMA, M.M. Forest soil Collembola. Do tree introductions make a difference? Pedobiologia, v.41, p.131-138, 1997.

PONGE, J.F. Biocenoses of Collembola in Atlantic temperate grass-woodland ecosystems. Pedobiologia, v.37, p.223-244, 1993.

POTAPOV, M. Isotomidae. In: DUNGER, W. (Ed.). Synopses on Palaearctic Collembola. Görlitz: Staatlisches Museum für Naturkunde Görlitz, 2001. 603p.

R DEVELOPMENT CORE TEAM. R: a language and environment for statistical computing. Vienna: R Foundation for Statistical Computing, 2006.
SALAMON, J.A.; SCHAEFER, M.; ALPHEI, J.; SCHMID, B.; SCHEU, S. Effects of plant diversity on Collembola in an experimental grassland ecosystem. Oikos, v.106, p.51-60, 2004.

SALAMON, J.A.; SCHEU, S.; SCHAEFER, M. The Collembola community of pure and mixed stands of beech (Fagus sylvatica) and spruce (Picea abies) of different age. Pedobiologia, v.51, p.385-396, 2008.

SCHEU, S.; ALBERS, D.; ALPHEI, J.; BURYN, R.; KLAGES, U.; MIGGE, S.; PLATNER, C.; SALAMON, J.A. The soil fauna community in pure and mixed stands of beech and spruce of different age: trophic structures and structuring forces. Oikos, v.101, p.225-238, 2003.

SILESHI, G. The excess-zero problem in soil animal count data and choice of appropriate models for statistical inference. Pedobiologia, v.52, p.1-17, 2008.

SINGH, S.B. Preliminary observations on the food preference of certain Collembola (Insecta). Revue d'Ecologie et de Biologie du Sol, v.4, p.461-467, 1969.

SOUSA, J.P.; DA GAMA, M.M.; PINTO, P.; KEATING,A.; CALHÔA, F.; LEMOS, M.; CASTRO, C.; LUZ, T.; LEITÃO, P.; DIAS, S. Effects of land-use on Collembola diversity patterns in a Mediterranean landscape. Pedobiologia, v.48, p.609-622, 2004.

TAKEDA, H. Dynamics and maintenance of collembolan community structure in a forest soil system. Researches on Population Ecology, v.29, p.291-346, 1987.

TAKEDA, H.; ICHIMURA, T. Feeding attributes of four species of Collembola in a pine forest soil. Pedobiologia, v.25, p.373-381, 1983.

TANAKA, S.; KITAZAWA, Y. Collembolan communities on the campus of UOEH and in an adjacent natural forest. Journal of UOEH, v.4, p.313-325, 1982.

TER BRAAK, C.J.F.; `SMILAUER, P. Canoco reference manual and canodraw for Windows user's guide: software for canonical community ordination. Version 4.5. Ithaca: Microcomputer Power, 2002. 500p.

VERHOEF, H.A. Water balance in Collembola and its relation to habitat selection: water content, haemolymph osmotic pressure and transpiration during an instar. Journal of Insect Physiology, v.27, p.755-760, 1981.

WATANABE, H. Effect of stand change on soil macro animals. Journal of Japanese Forest Society, v.55, p.291-295, 1973.

YOSHIDA, T.; HIJI, N. Seasonal distribution of Xenylla brevispina (Collembola) in the canopy and soil habitat of a Cryptomeria japonica plantation. Pedobiologia, v.50, p.235-242, 2006a.

YOSHIDA, T.; HIJII, N. Spatiotemporal distribution of aboveground litter in a Cryptomeria japonica plantation. Journal of Forest Research, v.11, p.419-426, $2006 \mathrm{~b}$.

YOSHIDA, T.; HIJII, N. Vertical distribution and seasonal dynamics of arboreal Collembolan communities in a Japanese cedar (Cryptomeria japonica D. Don) plantation. Pedobiologia, v.49, p.425-434, 2005.

Received on September 25, 2008 and accepted on January 19, 2009 